Arq. Bras. Med. Vet. Zootec., v.69, n.4, p.877-882, 2017

\title{
Evaluation of the cryosurgery for treatment of squamous cell carcinoma in cats
}

\author{
[Avaliação da criocirurgia no tratamento do carcinoma de células escamosas em gatos] \\ L.O.C. Prado, V.J.V. Rossetto, L.M.C.R. Carvalho, A.P. Ferreira, \\ L.M. Matsubara, J.C.Z. Rodrigues, C.V.S. Brandão
}

Faculdade de Medicina Veterinária e Zootecnia - Universidade Estadual Paulista - UNESP - Botucatu,SP

\begin{abstract}
The cryosurgery is a very useful therapy for the treatment of a variety of neoplastic and non-neoplastic processes. Nevertheless, it is still poorly described as an option for the treatment of specific cutaneous neoplasms, such as squamous cell carcinoma. The purpose of the present study was to analyze the clinical response of cryosurgery for the treatment of squamous cell carcinoma in cats. For this 13 squamous cell carcinoma lesions were selected in 11 cats, diagnosed through citopathological and/or histopathological examinations. The lesions were frozen using liquid nitrogen spray, and the evaluations were performed in the moment of freeze and approximately every 15 days until the wound was completely healed. The response of cryosurgery was considered complete with tumoral remission on $38.5 \%$ of the cats, and partial on $46.1 \%$. The main complications included crusting and nostril stenosis. The presented results suggested that cryosurgery is effective and may be a viable option for the treatment of squamous cell carcinoma in cats. The effectiveness of the therapy; however, depends on the correct selection of the candidates for cryosurgery based on the lesion size, and the attendance to some criteria, such as the freezing time and post-operative care.
\end{abstract}

Keywords: epidermoid carcinoma, freezing, skin neoplasms

\section{RESUMO}

A criocirurgia tem se mostrado uma terapia de grande auxílio no tratamento de uma variedade de processos neoplásicos e não neoplásicos. Apesar disso, ainda é pouco descrita a utilização da criocirurgia como opção de tratamento de neoplasias cutâneas específicas, como o carcinoma de células escamosas. Objetivou-se com o presente estudo analisar a resposta clínica da criocirurgia para o tratamento do carcinoma de células escamosas em gatos. Para isso, foram selecionadas 13 lesões do tipo carcinoma de células escamosas em 11 gatos, diagnosticadas por meio de análise citopatológica e/ou histopatológica. As lesões foram congeladas por meio de nitrogênio líquido na forma de spray, e as avaliações realizadas no momento do congelamento e aproximadamente a cada 15 dias, até a completa cicatrização da ferida. A resposta da criocirurgia foi considerada completa, com remissão tumoral em $38,5 \%$ dos gatos e parcial em 46,1\% destes. As principais complicações verificadas incluíram a formação de crostas e estenose de narina. Os resultados apresentados no presente estudo sugerem que a criocirurgia é efetiva e pode ser uma opção viável para o tratamento do carcinoma de células escamosas em gatos. O sucesso do tratamento, entretanto, depende da correta seleção dos candidatos à técnica quanto ao tamanho da lesão, e do atendimento a alguns critérios, como o tempo de congelamento e os cuidados pós-operatórios.

Palavras-chave: carcinoma epidermoide, congelamento, neoplasias cutâneas

Recebido em 4 de novembro de 2016

Aceito em 3 de dezembro de 2016

E-mail: leovet.prado@gmail.com 


\section{INTRODUCTION}

Cryosurgery is a therapeutic modality for cutaneous neoplasms and consists of using controlled low temperatures to destroy neoplastic and non-neoplastic tissues (Eurides et al., 2008; Gage et al., 2009).

The procedure is considered safe, as it requires less anesthesia time (Queiroz and Matera, 2003). Moreover, it presents better cosmetic results and lower morbidity than the conventional surgery (Hoffmann and Bischoff, 2001).

This procedure is appropriate for the treatment of several superficial cutaneous lesions, such as benign and malignant neoplasms (Kufik, 1994; Zouboulis, 1998), and when conventional surgery cannot be performed due to associated comorbidities or anatomic location of the lesion (Ruslander et al., 1997).

Among the malignant neoplasms, the squamous cell carcinoma, an erosive and ulcerated epidermal neoplasm with friable aspect (Rodaski and Werner, 2008), may be satisfactorily treated by cryosurgery, since this procedure allows for adequate security margins (Thomson, 2007; Rodaski and Werner, 2008).

Due to the small number of prospective studies on the subject, the aim of the present study was to analyze the clinical response of cryosurgery for the treatment of squamous cell carcinoma in cats.

\section{MATERIAL AND METHODS}

We evaluated cats with squamous cell carcinoma lesions, diagnosed by cytopathological and/or histopathological examinations. Lesions smaller than $1 \mathrm{~cm}^{2}$ width were diagnosed preferably by cytopathological examination.

The animals were submitted to clinical evaluation and laboratorial examinations, including complete blood count and biochemical profile. Thoracic radiographs and abdominal ultrasound were also performed to search for metastasis and the definition of tumor staging. All the selected animals had no clinical or laboratory abnormalities, and the absence of metastasis.
The tumors were classified according to lesion size as smaller than $1 \mathrm{~cm}^{2}$ width, from $1.1 \mathrm{~cm}^{2}$ to $3 \mathrm{~cm}^{2}$, and larger than $3 \mathrm{~cm}^{2}$.

To freeze the lesions, the animals were tranquilized with acepromazine (Acepran 0.2\%, Univet, São Paulo, SP, Brazil) at a dose of $0.1 \mathrm{mg} / \mathrm{kg}$, intramuscularly. The anesthesia was induced with propofol (Propovan ${ }^{\circledR}$, Cristália. São Paulo, SP, Brazil) at dose effect, intravenously, and maintained with isoflurane (Isoforine ${ }^{\circledR}$, Cristália. São Paulo, SP, Brazil) diluted in oxygen.

The lesions were frozen using an cryosurgery device CRY-AC 3 (Brymill Cryogenic Systems, Ellington, CT, USA) to spray the liquid nitrogen. The diameter of the tip chosen was proportional to the lesion. The liquid nitrogen was sprayed at a distance of $1 \mathrm{~cm}$ from the tumor, and with a security margin of $20 \mathrm{~mm}$. The freezing time was 60 seconds (Graham, 1983). In case of multiple lesions, they were individually frozen in a single procedure. The thawing time was defined by the disappearance of the ice halo around the tumor. All the lesions were submitted to three cycles of freezing-thawing. The protruding lesions were reduced in size reduced by a tangential incision at the skin level using a scalpel blade.

At post-operative the animals received meloxicam at a dose of $0.05 \mathrm{mg} / \mathrm{kg}$, orally, every 24 hours, during three days; cefalexine at a dose of $30 \mathrm{mg} / \mathrm{kg}$, orally, every 12 hours, during five days; and tramadol hydrochloride at a dose of $2 \mathrm{mg} / \mathrm{kg}$ of, orally, every eight hours, during two days. The owners were instructed to clean the wounds using $0.9 \%$ saline and clorhexidine solution at a dilution of $10 \mathrm{mg} / \mathrm{ml}$, twice daily, and to maintain the animals with the elizabethan collar.

The lesions were evaluated in the moment of freezing and approximately every 15 days until the complete healing of the wound. Another freezing procedure was performed when verified tumoral recurrence or residual lesion. The confirmation of the tumoral recurrence or residual lesion was performed by cytopathological or histopathological examinations.

At every procedure, the clinical response for the cryosurgery was considered as complete 
response (CR): complete disappearance of the tumour with total reepithelization of the wound; partial response $(\mathrm{PR})$ : reduction of the tumoral area above or equal to $50 \%$; and absence of response (AR): reduction of the tumoral area of less than $50 \%$ or tumoral progression.

The other variables analyzed were age and sex of the patients, the size and anatomical localization of the lesions, presence or absence of ulceration, number of required procedures, interval between the procedures, occurrence of metastasis after treatment, wound healing time, and the existence of eventual complication inherent to the cryosurgical procedure.

\section{RESULTS}

A total of 13 squamous cell carcinoma lesions in 11 mixed breed cats were evaluated. Seven $(63.3 \%)$ cats were female and four $(36.6 \%)$ males. The average age was 10.5 years ( 7 to 14 years). All of them presented depigmented skin and free exposure to sunlight.

The information regarding the lesions and treatment, such as anatomical location, tumoral size, number of freezing sessions, time of treatment and clinical response are described in Table 1.

The response to the cryosurgery was considered complete $(\mathrm{CR})$ in $38.5 \%(\mathrm{n}=5)$ of the lesions; partial (PR) in $46.1 \%(n=6)$, and absent $(A R)$ in $15.4 \%(n=2)$ (Fig. 1). The average number of freezing sessions was 2.38 with mean follow-up of 87 days (54 days to 150 days). Taking into consideration specifically the lesions with complete response, 1.8 sessions were performed on average with mean treatment time of 66 days.

The major complications related to the cryosurgical treatment included scab formation $(92.3 \% ; 12 / 13)$, infection of the surgical site $(46.2 \% ; 6 / 13)$ and nostril stenosis $(38.5 \% ; 5 / 13)$.

\section{DISCUSSION}

The squamous cell carcinoma affects more frequently middle-aged to old animals ( 9 years to 14 years) of depigmented skin (Rodaski and Werner, 2008), as presented in the present study. Animals with depigmented skin and lacking fur are more predisposed to the development of malignant neoplasms due to the chronic exposure of ultraviolet light (Daleck et al., 2008; Bellei et al., 2006). The chronic exposure to ultraviolet light results in damage of the cellular DNA that generates genetic mutations and consequently the neoplastic transformation (Parreira and Keglevich, 2005). In fact, in the present study, the lesions were located in glabrous regions, as nasal plane and ear pina.

Additionally, there is no sexual predisposition to squamous cell carcinoma in cats (Kraegel and Madewell, 2004), although, as verified by Scopel et al. (2006) and in the present study, the prevalence of females was higher than males.

Table 1. Distribution of the squamous cell carcinoma lesions in cats, regarding the anatomical location, tumoral size, number of sessions, time of evaluation and response to the cryosurgical treatment

\begin{tabular}{|c|c|c|c|c|c|}
\hline Lesion & Location & Size & $\begin{array}{l}\text { Number of } \\
\text { sessions }\end{array}$ & $\begin{array}{l}\text { Treatment } \\
\text { period }\end{array}$ & Response \\
\hline 1 & Nasal plane & $\leq 1 \mathrm{~cm}^{2}$ & 2 & 54 days & CR \\
\hline 2 & Nasal plane & 1,1 a $3 \mathrm{~cm}^{2}$ & 2 & 72 days & $\mathrm{CR}$ \\
\hline 3 & Nasal plane & $\leq 1 \mathrm{~cm}^{2}$ & 1 & 54 days & CR \\
\hline 4 & Ear pina & $>3 \mathrm{~cm}^{2}$ & 2 & 78 days & CR \\
\hline 5 & Nasal plane & $>3 \mathrm{~cm}^{2}$ & 2 & 72 days & CR \\
\hline 6 & Nasal plane & 1,1 a $3 \mathrm{~cm}^{2}$ & 2 & 57 days & PR \\
\hline 7 & Ear pina & 1,1 a $3 \mathrm{~cm}^{2}$ & 3 & 147 days & PR \\
\hline 8 & Ear pina & 1,1 a $3 \mathrm{~cm}^{2}$ & 3 & 147 days & PR \\
\hline 9 & Nasal plane & $\leq 1 \mathrm{~cm}^{2}$ & 3 & 72 days & PR \\
\hline 10 & Nasal plane & $\leq 1 \mathrm{~cm}^{2}$ & 5 & 150 days & PR \\
\hline 11 & Nasal plane & $\leq 1 \mathrm{~cm}^{2}$ & 4 & 109 days & PR \\
\hline 12 & Nasal plane & 1,1 a $3 \mathrm{~cm}^{2}$ & 1 & 59 days & $\mathrm{AR}$ \\
\hline 13 & Auditory canal & $\leq 1 \mathrm{~cm}^{2}$ & 1 & 61 days & $\mathrm{AR}$ \\
\hline
\end{tabular}

$\overline{\mathrm{CR}}=$ complete response, $\mathrm{PR}=$ partial response; $\mathrm{AR}=$ absent response 


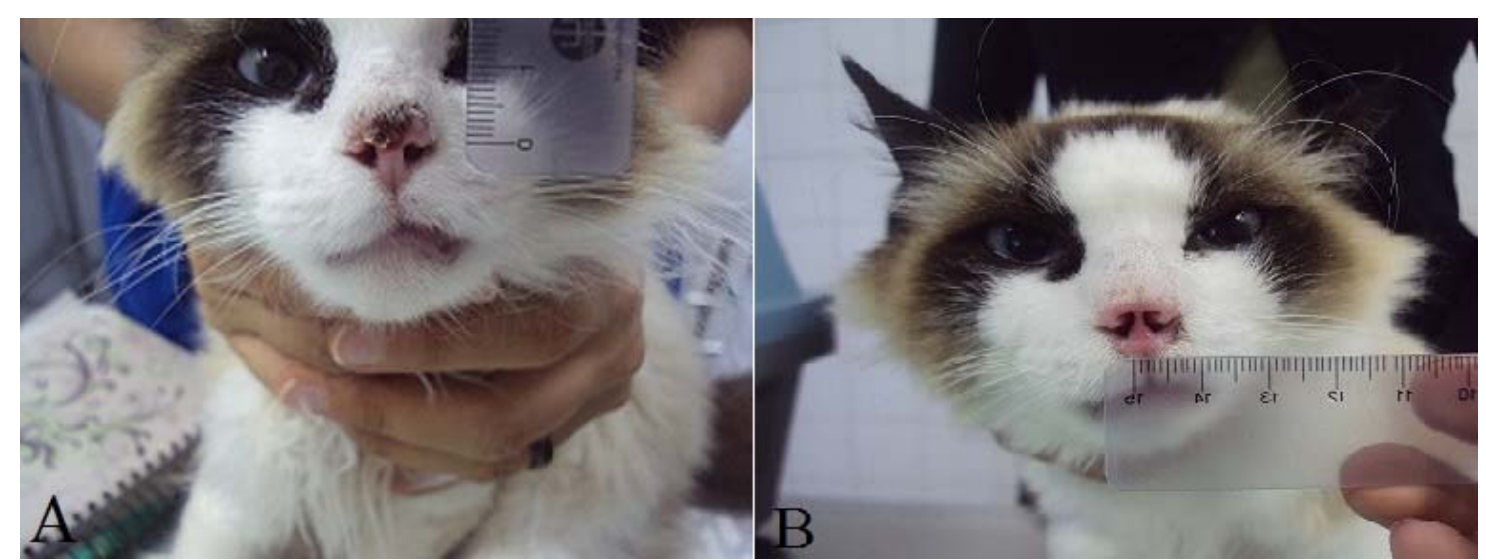

Figure 1. Cat corresponding to lesion 3 submitted to the cryosurgery. A: Aspect of the lesion before the first cryosurgery session. B: complete response after 54 days from the first cryosurgery session. Note the more cosmetic aspect of the nasal plane with increasing of the diameter of the nostrils

The response to cryosurgery in the present study was considered lower than the verified by Lucas and Larson (2006), evaluating the response to cryosurgery in lesions frozen by a minimum freezing time of 90 seconds, with complete remission in $80 \%$ of them. It is believed, therefore, that the disparity of the results may be justified by the longer freezing time in the aforementioned study.

Queiroz et al. (2008), however, evaluating the response of cryosurgery in lesions frozen by a minimum freezing time of 30 to 60 seconds, similar to the present study, verified complete remission in $100 \%$ of them. As in the present study, the authors described the majority of the lesions $(60 \%)$ as smaller than $1 \mathrm{~cm}^{2}$, all of them diagnosed by histopathological examination. Nevertheless, the lesions smaller than $1 \mathrm{~cm}^{2} \mathrm{n}$ our study were diagnosed preferably by cytopathological examination, so that the partial excision would not interfere in the results. Obtaining a representative tissue sample from such a small lesion can result in freezing of a non -neoplastic bed and thus explain the discrepancy of the results.

Although minor lesions are usually less invasive and present better response to local therapies, lesions 9, 10 and 11, smaller than $1 \mathrm{~cm}^{2}$, presented partial response to the cryosurgical treatment. We believe that this is possibly due to the not commitment of the owners in restricting their animal's direct sunlight exposure after the cryosurgery. Additionally, this can be justified by other aspects that were not evaluated, as well as those inherent to the neoplasm itself, such as malignancy grade.

Furthermore, there was an absence of response in two animals (lesions 12 and 13) due to tumoral dissemination and infection. The animal of the lesion 12 presented tumor cell dissemination to the upper lip and metastasis to the submandibular lymphnodes, probably, due to frequent licking of the labial region and self injury (Gross et al., 2005). Regarding the metastasis, the squamous cell carcinoma is a locally aggressive neoplasm with low metastatic potential (Runslander et al., 1997). In advanced stages and with inflammatory inducement, however, the squamous cell carcinoma can result in metastasis to the local lymphnodes and lungs (Scott et al., 2001; Thomson, 2007; Northrup and Gieger, 2010).

Regarding lesion 13, located in the auditory canal, the absence of response to cryosurgery may be justified by the glabrous location of the lesion, which decreases the sunlight protection of the skin, as well as the concomitant presence of external otitis, an inflammatory promoting factor that induces carcinogenesis (Rogers, 1998; Scott et al., 2001).

Still, in regards to the complications, we highlight scab formation and nostril stenosis. Scabs are probably due to the cryosurgical effects, such as increased vascular permeability and blood supply interruption, resulting consequently in tecidual necrosis and scab formation (Hoffman and Bischof, 2002). According to some studies, scab formation is one 
of the most common complications secondary to cryosurgery (Clarke, 1991; Lucas and Larson, 2006).

Scab formation associated to exuberant granulation tissue formation can also explain the nostril stenosis and obstruction of the upper airway (Queiroz and Matera, 2003). Because of the nostril stenosis, the animals in the present study were submitted to the placement of a nasopharyngeal catheter in order to act as a mechanical barrier to the granulation tissue formation, and to preserve the nostril patency and consequently the respiratory function (Novo and Kramek, 1999; Rabelo and Crowe, 2005). Therefore, the nasopharyngeal catheter was maintained until the complete reepithelization of the lesion and/or the resolution of the respiratory distress.

\section{CONCLUSIONS}

Cryosurgery may be a viable option for the treatment of squamous cell carcinoma in cats. The therapy tends to be effective, as long as some selection criteria for the patients are established as well as post-operative care provided. In this context, the freezing time of the lesions may be a determinant factor to the success of cryosurgery. For the real effectiveness of the therapy, however, further studies are necessary.

\section{REFERENCES}

BELLEI, M.H.M.; NEVES, D.S.; GAVA, A. et al. Prevalência de neoplasias cutâneas diagnosticadas em caninos no estado de Santa Catarina, Brasil, no período entre 1998 a 2002. Rev. Ciênc. Agrovet., v.5, p.73-79, 2006.

CLARKE, R.E. Cryosurgical treatment of feline cutaneous squamous cell carcinoma. Aust. Vet. Pract., v.21, p.148-153, 1991.

DALECK, C.R.; NARDI, A.B.; RODASKI, S. Oncologia em cães e gatos. São Paulo: Roca, 2008. 606p.

EURIDES, D.; DALECK, C.R.; SILVA, L.A.F.; SILVA, M.S.B. Criocirurgia. In: DALECK, C.R.; NARDI, A.B.; RODASKI, S. Oncologia em cães e gatos. São Paulo: Roca, 2008. p.195204.
GAGE, A.A.; BAUST, J.M.; BAUST, J.G. Experimental cryosurgery investigations in vivo. Cryobiology, v.59, p.229-243, 2009.

GRAHAN, G.F. Statistical data on malignant tumors in cryosurgery. J. Vet. Surg. Oncol., v.9, p.228-246, 1983.

GROSS, T.L.; IHRKE, P.J.; WALDER, E.J.; AFFOLTER, V.K. Skin diseases of the dog and cat: clinical and histopathologic diagnosis. 2.ed. Oxford: Blackwell Publishing Company, 2005. 944p.

HOFFMANN, N.E.; BISCHOF, J.C. Cryosurgery of normal and tumor tissue in the dorsal skin flap chambre: part. 1 - termal response. J. Biomech. Eng., v.123, p.301-309, 2001.

HOFFMANN, N.E.; BISCHOF, J.C. The cryobiology of cryosurgical injury. Urology, v.60, p.40-49, 2002.

KRAEGEL, S.A.; MADEWELL, B.R. Tumores da pele. In: ETTINGER, S.J.; FELDMANN, E.C. Tratado de medicina interna veterinária. 5.ed. Rio de Janeiro: Guanabara/Koogan, 2004. p.555-557.

KUFLIK, E.G. Cryosurgery update. J. Am. Acad. Dermatol., v.31, p.925-944, 1994.

LUCAS, R.; LARSON, C.E. Cryotherapy in veterinary clinic: evaluation of its practicability and effectiveness in feline squamous cell carcinoma. Braz. J. Vet. Res. Anim. Sci., v.43, p.33-42, 2006.

NORTHRUP, N.; GIEGER, T. Tumors of the skin, subcutis and other soft tissues. In: HENRY, C.J.; HIGGINBOTHAM, M.L. Cancer management in small animal practice. Missouri: Sunders/Elsevier, 2010. p.299-328.

NOVO, R.E.; KRAMEK, B. Surgical repair of nasopharyngeal stenosis in a cat using a stent. $J$. Am. Anim. Hosp. Assoc., v.35, p.251-256, 1999.

PARREIRA, I.M.; KEGLEVICH, S. As neoplasias em cães. Encicl. Biosfera, n.1, p.1-32, 2005.

QUEIROZ, G.F.; MATERA, J.M. Princípios gerais de criocirurgia no tratamento de tumores em pequenos animais: revisão de literatura. Rev. Educ. Cont. CRMV-SP., v.6, p.53-62, 2003. 
QUEIROZ, G.F.; MATERA, J.M.; DAGLI, M.L.Z. Clinical study of cryosurgery efficacy in the treatment of skin and subcutaneous tumors in dogs and cats. Vet. Surg., v.37, p.438-443, 2008.

RABELO, R.C.; CROWE, D.T. Fundamentos de terapia intensiva veterinária em pequenos animais - condutas no paciente crítico. Rio de Janeiro: L.F. Livros de Veterinária, 2005. 772p.

RODASKI, S.; WERNER, J. Neoplasias de pele. In: DALECK, C.R.; NARDI, A.B.; RODASKI, S. Oncologia em cães e gatos. São Paulo: Roca, 2008. p.253-279.

ROGERS, K.S. Tumors of the ear canal. Vet. Clin. N. Am. Small Anim. Pract., v.18, p.859$867,1988$.

RUSLANDER, D.; KASER-HOTZ, B.; SARDINAS, J.C. Cutaneous squamous cell carcinoma in cats. Comp. Cont. Educ. Pract., v.19, p.1119-1129, 1997.
SCOPEL, D.; SPADER, M.B., GUIM, T.N. et al. Estudo Retrospectivo da Casuística de Carcinoma de células Escamosas em felinos, bovinos, caninos, equinos e ovinos entre os anos de 2002 e 2006. In: CONGRESSO DE INICIAÇÃO CIENTIFICA e ENCONTRO DE PÓS-GRADUAÇÃO, Pelotas: UFPEL, 2007.

SCOTT, D.W.; MILLER, W.H.; GRIFFIN, C.E. Dermatologia dos pequenos animais. 6.ed. Philadelphia: Saunders Company, 2001. 1528p.

THOMSON, M. Squamous cell carcinoma of the nasal planum in cats and dogs. Clin. Tech. Small. Anim. Pract., v.22, p.42-45, 2007.

ZOUBOULIS, C.C. Cryosurgery in dermatology. Eur. J. Dermatol., v.8, p.466-474, 1998. 